\title{
Water Footprints and Sustainable Water Allocation
}

\author{
Arjen Y. Hoekstra ${ }^{1, *}$, Ashok K. Chapagain ${ }^{2}$ and Guoping Zhang ${ }^{2}$ \\ Received: 23 December 2015; Accepted: 23 December 2015; Published: 25 December 2015 \\ Academic Editor: Marc A. Rosen \\ 1 Twente Water Centre, University of Twente, P.O. Box 217, 7500 AE Enschede, The Netherlands \\ 2 Water Footprint Network, International Water House, Bezuidenhoutseweg 2, 2594 AV The Hague, \\ The Netherlands; ashok.chapagain@waterfootprint.org (A.K.C.); \\ guoping.zhang@waterfootprint.org (G.Z.) \\ * Correspondence: a.y.hoekstra@utwente.nl; Tel.: +31-53-489-3880
}

\begin{abstract}
Water Footprint Assessment (WFA) is a quickly growing research field. This Special Issue contains a selection of papers advancing the field or showing innovative applications. The first seven papers are geographic WFA studies, from an urban to a continental scale; the next five papers have a global scope; the final five papers focus on water sustainability from the business point of view. The collection of papers shows that the historical picture of a town relying on its hinterland for its supply of water and food is no longer true: the water footprint of urban consumers is global. It has become clear that wise water governance is no longer the exclusive domain of government, even though water is and will remain a public resource with government in a primary role. With most water being used for producing our food and other consumer goods, and with product supply chains becoming increasingly complex and global, there is a growing awareness that consumers, companies and investors also have a key role. The interest in sustainable water use grows quickly, in both civil society and business communities, but the poor state of transparency of companies regarding their direct and indirect water use implies that there is still a long way to go before we can expect that companies effectively contribute to making water footprints more sustainable at a relevant scale.
\end{abstract}

Keywords: green, blue, grey water footprint; water scarcity; water pollution; sustainability; efficiency; equity; water stewardship

\section{Introduction}

The scientific field of Water Footprint Assessment (WFA) is rapidly progressing, evidenced by the exponential growth in the number of articles in this field. With over 140 scientific papers on "water footprint" published in 2014 in the Web of Science catalogue, research in the water footprint has become more intensive than research in the ecological footprint. WFA is the analysis of the link between human consumption and the appropriation of fresh water to produce the products consumed [1]. The water footprint (WF) is a multi-dimensional measure of freshwater used both directly and indirectly by a producer or consumer. The consumptive WF includes a green and blue component, referring to consumption of rainfall and surface/groundwater respectively; the degradative $\mathrm{WF}$, the so-called grey $\mathrm{WF}$, represents the volume of water required to assimilate pollutants entering freshwater bodies. The WF of consumption by people within a certain area consists of an internal WF-the freshwater consumption and pollution within the area-and an external WF-the freshwater consumption and pollution elsewhere for making products imported by and consumed within the area considered. In this way, the WF concept is closely linked to the concept of virtual water trade. Trade in water-intensive commodities causes a saving of water resources for an importing region, since the region doesn't need to use its internal water resources 
to produce them locally. In order to study the environmental sustainability of water use in a river basin, the WF needs to be considered in the context of the maximum sustainable WF, which depends on the available water resources in the basin. The maximum sustainable blue WF in a river basin refers to the volume of renewable freshwater that is maximally available over time within a year for consumptive uses, given available runoff, storage possibilities and environmental flow requirements. A distinction can be made between the maximum sustainable ground-WF, considering groundwater recharge, maximum acceptable groundwater level decline and required base flow to the river, and the maximum sustainable surface-WF. The maximum sustainable grey WF in a river basin is determined by the available runoff to assimilate pollutants. For understanding the efficiency of water use of a process or product, one needs to consider the WF of the process or product in the context of what is reasonably possible given best available technology and practice, for which benchmarks are becoming increasingly available. Equity of water use can be studied by comparing the WFs across communities and by comparing the WF of different people to fair shares given the limited availability.

This Special Issue is a collection of papers advancing the WFA field or showing innovative applications. The first seven papers are geographic WFA studies, from the urban to the continental scale. Then there are five papers with a global scope, followed by five papers that focus on WF and water stewardship from the business point of view. In this editorial we position the papers in the on-going development of the field and draw some general conclusions.

\section{WFA from Urban to Continental Scale}

The ecological footprint concept, which looks at land requirements to sustain consumption, is rooted in the recognition that the essence of cities is that they inhabit concentrations of people relying on the rural surroundings regarding their food supply, thus having a footprint that goes beyond the area of the city itself [2]. In the field of water footprint assessment, with most studies carried out at the river basin, national and global level, application at the urban level is at its infancy. In this Special Issue, Paterson et al. [3] provide the first review of research on the water footprint of cities. They observe that a range of methods for estimating the WF of consumption is being used. As set out in Hoekstra et al. [4], the bottom-up approach is to multiply consumption volumes in an area by the WFs of the products consumed, measured at the place of production, while the top-down approach measures the WF of consumption in an area as the WF of production in the area plus the virtual water imports to the area minus the virtual water exports. Other approaches rely on the use of environmentally extended input-output (EEIO) models, which use economic input-output tables and thus consider sector level data, and life cycle assessment (LCA) models, which rely on databases to estimate the environmental, including water, and health impacts of products along their full life cycle. Paterson et al. [3] expect that increasingly we will find hybrid approaches, combining above approaches, to integrate scales and available datasets.

In their study of the WF of consumption in Beijing, Ma et al. [5] show that the WF of the consumers in this megacity is about ten times bigger than the volume of water resources available, which inevitably results in a significant external WF. Rushforth and Ruddell [6] quantify the WF of the Phoenix Metropolitan Area in Arizona, contributing methodologically by calculating intra-metropolitan area virtual water flows using commodity and labor flows.

The paper by De Miguel et al. [7] considers WF at the river basin level-still the most common level for water analyses-and takes a production rather than a consumption perspective, by considering the sustainability of the WF of crop production in the Duero River Basin in Spain. Their analysis shows that the current blue WF of crop growing causes a significant or severe water stress level in two to fives months per year and suggests that the foreseen future growth of irrigation could impede a movement to more sustainable water use, despite the Duero basin being relatively humid.

Lopez and Bautista-Capetillo [8] take a production perspective as well and study the impact of sowing date on the WF of dry beans production in the primary growing region in Mexico. This is 
the first study explicitly studying the sensitivity of WFs in crop production to the sowing date and illustrates that a sensible choice of sowing date may reduce the blue WF considerably.

The paper by Cazcarro et al. [9] is a study at the national level, taking the production perspective as well. It considers the changes in WF of crop production in Spain over a fifty-year interval, at provincial level, and shows the effects of different mechanisms, including an increase in overall production and a relative shift from growing cereals, legumes and fodder crops for domestic consumption to producing horticultural products, fruits and olives for export.

Mekonnen et al. [10] combine the consumption and production perspectives in a comprehensive study for Latin America and the Caribbean. This study is innovative by exploring ways to evaluate not only environmental sustainability of WFs at a high spatial resolution level but also economic efficiency of WFs based on WF benchmarks and social equity of water allocation by comparing WF levels across countries and contrasting WF levels in agriculture and levels of undernourishment. Ironically, the significant levels of undernourishment go together with abundant water and food production in the region and substantial use of land and water for producing export crops like soybean.

\section{Global Analysis}

In the past, various global WFAs have been published [11-17]. In this Special Issue, the study by Roson and Sartori [18] provides a first effort to consider inter-annual changes in the WF of production and consumption, for forty countries over the period 1995-2009. In particular, they find that the physical and economic impact of economic growth on water resources has been significantly lower than what it could have been. Schwarz et al. [19] analyze the changes in interregional virtual water flows between five world regions over the period 1986-2011. Their results confirm earlier studies $[20,21]$ showing that virtual water trade in the world has increased considerably over time. Furthermore they show that the shift towards high-value exports is beneficial for low-income countries from a regional economic water efficiency perspective, due to high trade values and low associated virtual water volumes. Economic water efficiency of trade has increased in all regions since 2000 and the return to virtual water exports is especially high in Europe.

Most of the international virtual water trade relates to trade in food [16]. Jackson et al. [22] are the first to assess the WF of global food aid, which had been excluded from previous virtual water trade studies. They find that the WF of global food aid in 2005 was equivalent to approximately $0.5 \%$ of the WF of international food trade and $2.0 \%$ of the WF of land grabbing (water appropriation associated with large agricultural land deals). Most notably, the study finds a significant overlap between countries receiving food aid and countries facing land grabbing.

The increasing focus on interactions between water, land, food, energy and climate leads to a call to consider water, land, carbon and other footprints more coherently [23] and put the different footprints in the context of local, regional or global planetary boundaries [23,24]. Berger et al. [25] address the issue that carbon footprint reduction in the transport sector through increased use of biofuels will inevitably increase the WF of the transport sector, thus confirming earlier findings [26]. In a life-cycle based case study on passenger cars, they show that biofuels can reduce the global warming potential by about $50 \%$ along the product life cycle, but that blue water consumption will increase by a factor 19 .

Fang et al. [27] have taken up the challenge to connect the environmental footprint literature [23] to the planetary boundaries literature [24] in a comprehensive study putting the carbon, water and land footprints of 28 selected nations in the context of allocated planetary boundaries. The study allocates the planetary boundaries for carbon emissions, water use and land use to the selected countries: the planetary carbon boundary is allocated to country-specific shares based on population size per country, while nation-specific environmental boundaries for land and water resources use are quantified through land and water availability within the national borders. Environmental sustainability ratios are calculated per country and type of footprint as the ratio of a footprint to 
the relevant boundary. From our point of view, the way of allocating planetary boundaries to country level will remain a contested issue, because any allocation mechanism is essentially normative, but the strength of an analysis as carried out by Fang et al. is that it shows the implications at country level given a certain allocation rationale. Future studies could show the implications of other allocation rationales, for example the case in which also the planetary boundaries for land and water are downscaled to countries based on population, just as in the case of the approach for downscaling the planetary boundary for greenhouse gas emissions.

\section{Corporate Water Footprints}

Since 2008 there has been an increasing interest in WFA for understanding corporate water sustainability, water risk and water stewardship [1,28]. In this Special Issue, Antonelli and Ruini [29] contribute by elaborating the specific case of Barilla, an Italian-based company that has adopted WF accounting as part of its corporate social responsibility strategy. The company's strategy is to develop so-called environmental product declarations showing the ecological, carbon and water footprint of their products. The study specifically explores the effect of different durum wheat varieties on the size and color composition of the water footprint, showing potential for saving blue water resources in a dry climate.

The paper by Chen [30] is the first WFA study for a Science Park, with a case for the Hsinchu Science Park in Taiwan. Employing an input-output model, the study shows that over the period 2001-2006 three of the six industrial sectors at the Science Park have become increasingly dependent on foreign water resources, alleviating the water shortage in Taiwan.

Ristic et al. [31] contribute to this Special Issue with a study on the WF of data centers, considering both the WF of cooling and the indirect WF of the energy used. It is estimated that outbound data traffic from data centers generates a WF of 1 to 205 liters per gigabyte (the high end of the range being roughly equal to the WF of $1 \mathrm{~kg}$ of tomatoes). Typically, energy consumption constitutes by far the greatest share of the WF of a data center.

Sojamo [32] addresses the important question whether corporate water stewardship-proactive corporate engagement in water management and governance-really offers a solution to global water challenges as often suggested, or can rather be regarded as a form of "blue-washing" and cover-up of efforts to secure continued and enhanced private access to scarce water resources. Based on the findings of a case study of corporations active in water stewardship initiatives in South Africa, the article suggests that the stewardship agenda would benefit from: explicit acknowledgement of power asymmetries between corporations and other parties; more careful and systematic evaluation and enhancement of legitimacy of corporations to engage in public good and common pool water resources; efforts to support stronger public institutions and to promote equal participation of civil society.

Transparency about the operational and supply-chain water consumption and pollution of a company is at the core of any effort in the direction of corporate water sustainability and water stewardship. Linneman et al. [33] scrutinize the water transparency of the largest 75 stock-listed companies in the Netherlands. They develop and apply an innovative method to rank companies based on their water transparency, which is defined as the extent to which a company publicly discloses information about its direct and indirect claim on freshwater resources and about what it does to reduce its claim. The method consists of a checklist that can be completed on the basis of information from annual reports, sustainability reports and websites of companies. Results show that there are large differences in transparency between and within sectors and that companies are reporting more about their operations than their supply chain. The highest transparency score was no more than $43 \%$ (at a scale of $0-100 \%$ ), with 34 out of the 75 companies even scoring 0 , indicating that transparency of business on water use may be growing, but is still at a very low level. 


\section{Conclusions}

The papers in this Special Issue and the development of the WFA field in general show that a major challenge remains the bridging of different spatial levels of analysis. Traditionally, water resource challenges have been regarded as mostly relevant at the local up to the river basin level. WF studies show that freshwater resources have a global character as well, because water use for producing export commodities can enhance local water use and scarcity, while import of water-intensive commodities can alleviate the pressure on local water resources. The historical picture of a town relying on its hinterland for its supply of water and food is no longer true: the water footprint of the consumers in a city is global. We are now in a stage in which we start to quantify and map such footprints, but we are still far off from understanding how to govern footprints in a sustainable way. It has become clear that wise water governance is no longer the exclusive domain of government-even though water is and will remain a public good with government in a primary role. Consumers, companies and investors have an important role to play as well. However, despite the quickly growing interest in sustainable water use, in both civil society and business communities, the poor state of transparency of companies regarding their direct and indirect water use implies that there is still a long way to go before we can expect that companies effectively contribute to making water footprints more sustainable at a relevant scale.

Author Contributions: Arjen Y. Hoekstra wrote the draft; all three authors contributed equally to the finalization of the paper.

Conflicts of Interest: The authors declare no conflict of interest.

\section{References}

1. Hoekstra, A.Y. The Water Footprint of Modern Consumer Society; Routledge: London, UK, 2013.

2. Rees, W.; Wackernagel, M. Urban ecological footprints: Why cities cannot be sustainable-And why they are a key to sustainability. Environ. Impact Assess. Rev. 1996, 16, 223-248. [CrossRef]

3. Paterson, W.; Rushforth, R.; Ruddell, B.L.; Konar, M.; Ahams, I.C.; Gironás, J.; Mijic, A.; Mejia, A. Water footprint of cities: A review and suggestions for future research. Sustainability 2015, 7, 8461-8490. [CrossRef]

4. Hoekstra, A.Y.; Chapagain, A.K.; Aldaya, M.M.; Mekonnen, M.M. The Water Footprint Assessment Manual: Setting the Global Standard; Earthscan: London, UK, 2011.

5. Ma, D.; Xian, C.; Zhang, J.; Zhang, R.; Ouyang, Z. The evaluation of water footprints and sustainable water utilization in Beijing. Sustainability 2015, 7, 13206-13221. [CrossRef]

6. Rushforth, R.R.; Ruddell, B.L. The hydro-economic interdependency of cities: Virtual water connections of the Phoenix, Arizona Metropolitan Area. Sustainability 2015, 7, 8522-8547. [CrossRef]

7. De Miguel, Á.; Kallache, M.; García-Calvo, E. The water footprint of agriculture in Duero River Basin. Sustainability 2015, 7, 6759-6780. [CrossRef]

8. Lopez, L.I.F.; Bautista-Capetillo, C. Green and blue water footprint accounting for dry beans (Phaseolus Vulgaris) in primary region of Mexico. Sustainability 2015, 7, 3001-3016. [CrossRef]

9. Cazcarro, I.; Duarte, R.; Martín-Retortillo, M.; Pinilla, V.; Serrano, A. How sustainable is the increase in the water footprint of the Spanish agricultural sector? A provincial analysis between 1955 and 2005-2010. Sustainability 2015, 7, 5094-5119. [CrossRef]

10. Mekonnen, M.M.; Pahlow, M.; Aldaya, M.M.; Zarate, E.; Hoekstra, A.Y. Sustainability, efficiency and equitability of water consumption and pollution in Latin America and the Caribbean. Sustainability 2015, 7, 2086-2112. [CrossRef]

11. Hoekstra, A.Y.; Hung, P.Q. Virtual Water Trade: A Quantification of Virtual Water Flows between Nations in Relation to International Crop Trade; UNESCO-IHE Value of Water Research Report Series; UNESCO-IHE: Delft, The Netherlands, 2002.

12. Hoekstra, A.Y.; Chapagain, A.K. Water footprints of nations: Water use by people as a function of their consumption pattern. Water Resour. Manag. 2007, 21, 35-48. [CrossRef] 
13. Hoekstra, A.Y.; Chapagain, A.K. Globalization of Water: Sharing the Planet's Freshwater Resources; Blackwell: Oxford, UK, 2008.

14. Mekonnen, M.M.; Hoekstra, A.Y. National Water Footprint Accounts: The Green, Blue and Grey Water Footprint of Production and Consumption; UNESCO-IHE Value of Water Research Report Series; UNESCO-IHE: Delft, The Netherlands, 2011.

15. Fader, M.; Gerten, D.; Thammer, M.; Heinke, J.; Lotze-Campen, H.; Lucht, W.; Cramer, W. Internal and external green-blue agricultural water footprints of nations, and related water and land savings through trade. Hydrol. Earth Syst. Sci. 2011, 15, 1641-1660. [CrossRef]

16. Hoekstra, A.Y.; Mekonnen, M.M. The water footprint of humanity. Proc. Natl. Acad. Sci. USA 2012, 109, 3232-3237. [CrossRef] [PubMed]

17. Chen, Z.-M.; Chen, G.Q. Virtual water accounting for the globalized world economy: National water footprint and international virtual water trade. Ecol. Indicat. 2013, 28, 142-149. [CrossRef]

18. Roson, R.; Sartori, M. A decomposition and comparison analysis of international water footprint time series. Sustainability 2015, 7, 5304-5320. [CrossRef]

19. Schwarz, J.; Mathijs, E.; Maertens, M. Changing patterns of global agri-food trade and the economic efficiency of virtual water flows. Sustainability 2015, 7, 5542-5563. [CrossRef]

20. Dalin, C.; Konar, M.; Hanasaki, N.; Rinaldo, A.; Rodriguez-Iturbe, I. Evolution of the global virtual water trade network. Proc. Natl. Acad. Sci. USA 2012, 109, 5989-5994. [CrossRef] [PubMed]

21. Clark, S.; Sarlin, P.; Sharma, A.; Sisson, S.A. Increasing dependence on foreign water resources? An assessment of trends in global virtual water flows using a self-organizing time map. Ecol. Informat. 2015, 26, 192-202. [CrossRef]

22. Jackson, N.; Konar, M.; Hoekstra, A.Y. The water footprint of food aid. Sustainability 2015, 7, 6435-6456. [CrossRef]

23. Hoekstra, A.Y.; Wiedmann, T.O. Humanity's unsustainable environmental footprint. Science 2014, 344, 1114-1117. [CrossRef] [PubMed]

24. Steffen, W.; Richardson, K.; Rockström, J.; Cornell, S.E.; Fetzer, I.; Bennett, E.M.; Biggs, R.; Carpenter, S.R.; de Vries, W.; de Wit, C.A.; et al. Planetary boundaries: Guiding human development on a changing planet. Science 2015. [CrossRef] [PubMed]

25. Berger, M.; Pfister, S.; Bach, V.; Finkbeiner, M. Saving the planet's climate or water resources? The trade-off between carbon and water footprints of European biofuels. Sustainability 2015, 7, 6665-6683. [CrossRef]

26. Gerbens-Leenes, W.; Hoekstra, A.Y. The water footprint of biofuel-based transport. Energy Environ. Sci. 2011, 4, 2658-2668. [CrossRef]

27. Fang, K.; Heijungs, R.; Duan, Z.; de Snoo, G.R. The environmental sustainability of nations: Benchmarking the carbon, water and land footprints against allocated planetary boundaries. Sustainability 2015, 7, 11285-11305. [CrossRef]

28. Sarni, W. Corporate Water Strategies; Earthscan: London, UK, 2011.

29. Antonelli, M.; Ruini, L.F. Footprint accounting: The case of the Barilla company. Sustainability 2015, 7, 6742-6758. [CrossRef]

30. Chen, H.-S. Using water footprints for examining the sustainable development of science parks. Sustainability 2015, 7, 5521-5541. [CrossRef]

31. Ristic, B.; Madani, K.; Makuch, Z. The water footprint of data centers. Sustainability 2015, 7, 11260-11284. [CrossRef]

32. Sojamo, S. Unlocking the "prisoner's dilemma" of corporate water stewardship in South Africa: Exploring corporate power and legitimacy of engagement in water management and governance. Sustainability 2015, 7, 6893-6918. [CrossRef]

33. Linneman, M.H.; Hoekstra, A.Y.; Berkhout, W. Ranking water transparency of Dutch stock-listed companies. Sustainability 2015, 7, 4341-4359. [CrossRef]

(C) 2015 by the authors; licensee MDPI, Basel, Switzerland. This article is an open access article distributed under the terms and conditions of the Creative Commons by Attribution (CC-BY) license (http:/ / creativecommons.org/licenses/by/4.0/). 